\title{
ARTIKELEN
}

\section{Protestanten verenigd voor of door de staat?}

\section{Onderhandelingen over de afbakening van een erkende eredienst in België (1999-2002)}

\author{
Jelle Creemers
}

\begin{abstract}
Dit artikel wil inzicht geven in onderhandelingen die van 1999 tot 2002 plaatsvonden tussen diverse protestantse partijen in België en leidden tot een uitbreiding van de erkende protestantse eredienst. Deze uitbreiding was met name vrije evangelische kerken tot nut, die bijgevolg konden delen in de voordelen die aan officiële overheidserkenning verbonden zijn. Het artikel beschrijft hun strategische keuzes in functie van volledige overheidserkenning en belicht in het bijzonder ook de actieve rol die de 'neutrale' Belgische staat speelde in de onderhandelingen over deze erkende eredienst.
\end{abstract}

In zijn vergelijkend overzicht van religie-staatverhoudingen beschouwt Jonathan Fox België als een land dat actief met een aantal religies samenwerkt (zij krijgen bepaalde voordelen die anderen niet krijgen), en Nederland als een staat die in algemene zin religie accommodeert (met minimale steun). ${ }^{1}$ Anders dan in Nederland, waar een door de staat gefaciliteerde verzuiling grotendeels uiteengevallen is in een bredere pluralisering en waar directe overheidssteun voor religie is afgebouwd, ${ }^{2}$ heeft de Belgische staat immers sinds napoleontische tijd een bijzondere relatie met een groeiend aantal levensbeschouwelijke structuren en organisaties opgebouwd en vastgehouden. ${ }^{3}$ Aan deze regeling is ook een reeks gunstmaatregelen verbonden. Ze staat in de Belgische geseculariseerde en liberale rechtsstaat flink ter discussie, maar houdt voorlopig goed stand. ${ }^{4}$ Ook de protestantse eredienst kan van rechten en gunstmaatregelen gebruikmaken, al kan slechts een

1 J. Fox, Political Secularism, Religion, and the State. A Time Series Analysis of Worldwide Data, Cambridge 2015, p. 44-45.

2 Zie 'The Netherlands: Principled Pluralism', in: J.C. Soper, K.R. den Dulk \& S.V. Monsma, The Challenge of Pluralism: Church and State in Six Demoncracies, Lanham 2017, p. 85-120.

3 Voor een recent overzicht van de Belgische wetgeving betreffende de erediensten in haar diversiteit en complexiteit, zie S. Wattier, Le financement public des cultes et des organisations philosophiques non confessionnelles. Analyse de constitutionnalité et de conventionnalité, Brussel 2016.

4 Ahmet Kuru zou de Belgische religie-staatverhouding, waarin de staat niet (zoals bijvoorbeeld in Frankrijk) assertief zoekt religie uit de publieke sfeer te bannen, duiden als 'passief secularisme'. Zie A.T. Kuru, Secularism and State Policies toward Religion: The United States, France, and Turkey, Cambridge/New York: 2009. Voor een recente, kritische bespreking van de Belgische religiestaatverhoudingen, zie L. Franken, 'State Support for Religion in Belgium: A Critical Evaluation', Journal of Church and State 2017, 1, p. 59-80. 
klein deel van de Belgische bevolking tot het protestantisme gerekend worden (ongeveer 2\%). ${ }^{5}$ De uitbreiding van de erkende protestantse eredienst in 2003, die in dit artikel ter bespreking staat, was met name vrije evangelische kerken tot nut, die bijgevolg konden delen in de voordelen die aan officiële overheidserkenning verbonden zijn.

Dit artikel volgt, na korte inleidende overwegingen, vier stappen. Eerst worden de belangrijkste partijen van dit verhaal gepresenteerd, en hun historische relaties in de context van de Belgische religie-staatverhoudingen. Daarna wordt bondig een eerste fase van (mislukte) schriftelijke onderhandelingen tussen de evangelische vertegenwoordigers en de burgerlijke overheden (van januari 1992 tot juni 1997) geschetst als een historische inleiding tot ons hoofdthema. Het centrale gedeelte behandelt een tweede onderhandelingsperiode tussen diverse protestantse belanghebbenden en vertegenwoordigers van de overheid, die plaatsvond tussen 1999 en 2002. De conclusie bespreekt de onderhandelingsstrategieën kritisch, legt interne spanningen inherent aan deze onderhandelingen bloot en evalueert de uitkomst van de onderhandelingen door een retrospectieve lens. Daarbij wordt de actieve rol die de 'neutrale' overheid speelde in haar relatie tot deze erkende eredienst in het bijzonder belicht.

\section{Afbakeningen en inleidende overwegingen}

In de onderhandelingen die centraal staan in dit artikel waren met name vertegenwoordigers van twee partijen betrokken: de Federale Synode van Evangelische en Protestante Kerken in België (hierna: Federale Synode of FS) en de Verenigde Protestantse Kerk in België (hierna: VPKB). Deze zullen verderop uitgebreider worden geïntroduceerd. De onderhandelingen hadden tot doel om een nieuw gezamenlijk en representatief orgaan voor de protestantse eredienst in zijn relatie met de overheid op te zetten. De onderhandelingen leidden uiteindelijk tot de oprichting van de Administratieve Raad van de Protestants-Evangelische Eredienst (ARPEE), die sinds 1 januari 2003 tot op de dag van vandaag de officiële gesprekspartner van de overheid voor de erkende protestantse eredienst is. ${ }^{6}$ De eerste onderhandelingen vonden plaats in de gebouwen van het (federaal) ministerie van Justitie in Brussel. Ze gingen daarna elders verder, meestal in de aanwezigheid van een vertegenwoordiger van de overheid. Tussen 13 januari 1999 en 20 november 2002 vonden 58 van zulke ontmoetingen plaats. In hetzelfde tijdsbestek onderhandelden de vertegenwoordigers van de FS en van de VPKB eveneens met andere protestanten, zowel schriftelijk als in fysieke vergaderingen. Deze onderhandelingen zijn ook opgenomen in dit artikel.

5 Er zijn geen officiële tellingen van godsdienstige affiliatie in België, maar metingen komen zelden boven de $2 \%$ uit. Zie de Swiss Megadatabase of Religious Affiliation in Europe (SMRE), online beschikbaar op www.smre-data.ch/en/data_exploring/region_cockpit\#/mode/dataset_ comparison/region/BEL/period/2010/presentation/bar, geraadpleegd op 8 maart 2018.

6 De ARPEE is opgericht op 9 november 2002, na positieve besluiten van beide betrokken synodes. Bij de oprichting werd overeengekomen dat de ARPEE vanaf 1 januari 2003 ten volle zou gaan functioneren. 
De analyse van de onderhandelingen, die in dit artikel wordt gepresenteerd, is met name gebaseerd op de notulen van deze onderhandelingssessies en op gerelateerde correspondenties. Mijn dank gaat uit naar de Uitvoerende Raad van de Federale Synode en naar het Dagelijks Bestuur van de Evangelische Alliantie Vlaanderen, die mij in functie van mijn onderzoek toegang gegeven hebben tot hun archieven. Naast deze papieren bronnen heb ik ook een aantal kernactoren uit de onderhandelingen (al dan niet uitgebreid) gesproken. ${ }^{7}$ Deze interviews waren zeker behulpzaam om de overheersende discoursen op te sporen en te duiden, maar alle geïnterviewden gaven ook aan dat de tijd hun herinnering van het precieze verloop van de onderhandelingen behoorlijk had vervaagd.

Dit artikel beschrijft de worstelingen van evangelische protestanten als een nieuwe religieuze minderheid in haar ontwikkelende relatie met de liberale overheid in België. Het vormt daarmee een interessante aanvulling op andere recente literatuur hierover, waarin met name de nadruk ligt op de opkomende islam. ${ }^{8}$ Auteurs als Veit Bader en Marcel Maussen wijzen met referenties naar de islam op de diversiteit van manieren waarop zowel overheden als de nieuwe minderheden zelf omgaan met de mogelijkheden en moeilijkheden van hun groeiende relatie. Bader wijst op twee (soorten) dilemma's waarmee nieuwe religieuze minderheden worden geconfronteerd in hun relatie met de liberale staat. ${ }^{9}$ Ten eerste wijst hij op het autonomiedilemma: in hoeverre weegt het verlangen naar autonomie op tegen het verlangen naar politieke bevestiging en invloed? Ten tweede zijn er de dilemma's betreffende organisatie, leiderschap, centralisatie en geïnstitutionaliseerde samenwerking. In het geval van de evangelische vrije kerken in België, centraal in dit artikel, is geleidelijk aan hun nadruk op autonomie verruild voor een queeste naar politieke bevestiging en invloed. De grote principiële en structurele vragen die daaraan gekoppeld zijn, zijn grotendeels al besproken in mijn eerdere artikelen over de periode $1982-1999 .{ }^{10}$ In dit artikel gaat het over het sluitstuk van de groeiende geïnstitutionaliseerde samenwerking: de uitwerking van een representatieve organisatie in samenwerking met andere (al dan niet geïnstitutionaliseerde) protestantse aanwezigheid in het land.

7 In het kader van mijn lopend FWO-onderzoek heb ik expertinterviews afgenomen en (al dan niet uitgebreide) gesprekken over deze onderhandelingen gehad met de volgende betrokken personen: Guy Liagre, Patrick Nullens, Jean-Louis Simonet, John van der Dussen. Bijzondere dank gaat uit naar John van der Dussen, toenmalige hoofdonderhandelaar aan de zijde van de FS en een onderhandelaar van de VPKB, die liever anoniem blijft. Zij hebben het artikel kritisch doorgenomen en me bijkomende informatie en suggesties ter verbetering aangereikt.

8 Zie bijvoorbeeld V. Bader, 'Dilemmas of Institutionalisation and Political Participation of Organised Religions in Europe. Associational Governance as a Promising Alternative', in: F. Colom González \& G. D’Amato (red.), Multireligious Society. Dealing with Religious Diversity in Theory and Practice, Oxon 2017, p. 152-178; M. Maussen, 'Institutional Change and the Incorporation of Muslim Populations: Religious Freedoms, Equality and Cultural Diversity', in: M. Burchardt \& I. Michalowski (red.), After Integration. Islam, Conviviality and Cententious Politics in Europe, Wiesbaden 2015, p. 79-104.

$9 \quad$ Bader 2017.

10 Naar deze publicaties wordt in de loop van het artikel op de meest gepaste plaatsen verwezen. 


\section{Evangelische kerken, protestantisme en religie-staatverhoudingen in België}

Na ruim een eeuw aanwezigheid van evangelische kerken op Belgisch grondgebied richtten in 198023 evangelische leiders samen een nieuwe Evangelische Alliantie in Vlaanderen (EAV) op. ${ }^{11}$ In de voorafgaande decennia hadden evangelische vrije kerken - kerken met een evangelische (of pinkster)spiritualiteit, die zichzelf primair begrijpen als lokale gemeenschappen van bekeerde Christusvolgelingen een substantiële groei in het land gekend. ${ }^{12}$ Rond 1980 konden enkele honderden, meestal kleine geloofsgemeenschappen geteld worden. De blik van deze nieuwe alliantie was vooral naar binnen gericht: ze wilde 'een platform zijn waarop we elkaar ontmoeten, stichten, opbouwen, stimuleren, activeren'. ${ }^{13}$ In 1987 werd de EAV omgevormd tot een vereniging zonder winstbejag (in Nederland: stichting) met een veel breder pallet aan doelstellingen. ${ }^{14}$ De EAV wilde zich nu aan haar leden dienstbaar stellen door (onder andere) 'het vertegenwoordigen van haar leden om vanuit haar ideologische gerichtheid (...) gebruik te maken van alle wettelijke faciliteiten die door de officiële instanties geboden worden om haar (...) doelstellingen te verwezenlijken, bijvoorbeeld op het terrein van de geschreven pers, radio- en televisie-uitzendingen, het verstrekken van godsdienstonderricht in de officiële onderwijsinstellingen, het verzorgen van aalmoezeniersdiensten voor zieken, militairen en gevangenen'. Het is duidelijk dat dit begrepen dient te worden in de context van de religie-staatregelgeving in België in haar toepassing op de kleine protestantse minderheid in het land.

In 1987 hadden evangelische vrije kerken in België geen directe relatie met de staat, ook al was de protestantse eredienst door de overheid erkend. De officiële relatie van de staat met de erkende protestantse eredienst verliep toen via de synodevoorzitter van de Verenigde Protestantse Kerk in België. De VPKB begon

11 Zie het persbericht over de oprichting van de EAV, persoonlijke archieven van S. Kaljouw (BE/ 942855/1665), Evadoc, Leuven. Het zij opgemerkt dat ook in 1847 al tot de oprichting van een Evangelische Alliantie in België besloten werd ('L'alliance Evangélique à Bruxelles', Le Glaneur Missionaire 1847, november, p. 132). Deze heeft echter geen continuiteit tot in de twintigste eeuw gekend.

12 Voor een hedendaagse vrijkerkelijke ecclesiologie, zie M. Volf, After Our Likeness: The Church as the Image of the Trinity, Grand Rapids 1998. Gedetailleerde historische analyses van de groei van de evangelische beweging in België in de twintigste eeuw richten zich meestal op een specifieke denominatie, maar er zijn ook enkele overzichtswerken en -artikelen te vinden. De lezer wordt voor meer achtergrond verwezen naar I. Demaerel, Tachtig jaar pinksterbeweging in Vlaanderen (1909-1989): een historisch onderzoek met korte theologische en sociologische analyse (licentiaatsthesis Universitaire Faculteit voor Protestantse Godgeleerdheid te Brussel), Brussel 1990; G. Lorein \& J.-L. Simonet, 'Le Protestantisme Evangélique non-E.P.U.B en Belgique', Le Messager Evangélique 1994; C. Godwin, 'The Recent Growth of Pentecostalism in Belgium', International Bulletin of Missionary Research 2013, 2, p. 90-94; T.J. Marinello, New Brethren in Flanders. The Origins and Development of the Evangelische Christengemeenten Vlaanderen, 1971-2008, Eugene 2013; A. Prins, The History of the Belgian Gospel Mission from 1918 to 1962 (diss. Evangelische Theologische Faculteit), Leuven 2015.

13 Zie het persbericht over de oprichting van de EAV, persoonlijke archieven van S. Kaljouw (BE/ 942855/1665), Evadoc, KADOC, Leuven.

14 Statuten van Evangelische Alliantie Vlaanderen, afgekort: 'E.A.V.', Belgisch Staatsblad 30 april 1987. 
in 1979 te functioneren als samensmelting van drie hervormde/gereformeerde tradities ${ }^{15}$ en werd de historische erfgenaam van de synode van zestien protestantse kerken die in 1839 was gevormd, negen jaar na de onafhankelijkheid van België, en die door de toenmalige minister van Binnenlandse Zaken De Theux in datzelfde jaar erkend werd als vertegenwoordiger van deze kerken bij de burgerlijke overheden. ${ }^{16}$ Net als de katholieke kerken en de joodse synagogen kregen de protestantse kerken van deze jonge synode overheidssteun in de vorm van salarissen voor hun pastors en financiële bijstand om hun erediensten te organiseren. ${ }^{17}$

Sinds 1839 hebben de structurele relaties tussen de staat en de religies in België een substantiële ontwikkeling doorgemaakt. In 1987, dus bij de oprichting van de EAV vzw (vereniging zonder winstbejag, i.e. stichting), konden niet minder dan zeven levensbeschouwingen van bestaande regelingen gebruikmaken. ${ }^{18}$ Deze regelingen behelsden toen naast steun voor lokale gemeenschappen ook het recht op de oprichting van gesubsidieerde vrije (= op een levensbeschouwing gestoelde) scholen, (door de overheid betaald) godsdienstonderricht in de eigen levensbeschouwing in openbare scholen, betaalde aalmoezeniersdiensten in het leger en in gevangenissen, en zendtijd op de openbare radio en televisie.

De opmerkelijke groei van evangelische vrije kerken in de voorafgaande decennia had ertoe geleid dat hun leiders in 1987 de toenmalige situatie als ongewenst beschouwden. De synode van de VPKB omvatte op dat moment ongeveer honderd kerken, waarvan de meeste een door de overheid gesubsidieerde predikant hadden. $\mathrm{Zij}$ wist zich eveneens verantwoordelijk voor de organisatie en verdeling van alle genoemde gunstmaatregelen. Tegelijkertijd bevond een substantieel groter aantal gemeenschappen met een protestants profiel - met name vrije kerken met evangelische en pinksterkarakteristieken - zich buiten deze synode, zonder structurele plaats in de Belgische regelgeving betreffende de protestantse minderheid. Het doel van de EAV, zoals we indirect zagen in de statuten, was om het ervaren monopolie van de VPKB te doorbreken en medezeggenschap te krijgen in de uitvoering van deze regelingen.

De VPKB werd opgericht door de synoden van de Hervormde Kerk van België en de Protestantse Kerk van België en de Kring België van de Gereformeerde Kerken. G. Liagre (red.), Tussen behouden en vernieuwen, Brussel 2005, p. 71.

16 Zie de statuten van de Unie van de Protestants-Evangelische Kerken van België van 23 april 1839 en de brief van de minister van Binnenlandse zaken van 18 mei 1839 betreffende deze statuten.

17 Voor een sterke analyse van de achtergrond en ontstaansgeschiedenis van het politieke gegeven van erkende erediensten en levensbeschouwingen in België, zie het eerste deel van L. Panafit, Quand le droit écrit l'Islam. L'intégration juridique de l'Islam en Belgique, Brussel 1999. Voor een gedetailleerde historiografie van de oprichting van de protestantse synode in 1839, zie H.R. Boudin, Les relations entre les Eglises protestantes et l'Etat en Belgique (1814-1839) (diss. Université Libre de Bruxelles), Brussel 1976. Voor een recent overzicht van de Belgische wetgeving betreffende de erediensten in haar diversiteit en complexiteit, zie Wattier 2016.

18 De anglicaanse eredienst, de katholieke eredienst, de islamitische eredienst, de Israëlitische eredienst, de orthodoxe eredienst, de georganiseerde vrijzinnigheid (humanisme) en de protestantse eredienst. Zie vorige voetnoot. Het zij opgemerkt dat ondanks officiële erkenning in 1974 de islamitische eredienst lange tijd in limbo heeft verkeerd wat betreft de volle uitvoering van de hem toegezegde rechten. Zie met name Panafit 1999. 


\section{7-1998: De de weg naar de oprichting van de FS en de onderhandelingen ${ }^{19}$}

Snel na haar oprichting als vzw bezocht een delegatie van de EAV de synodevoorzitter van de VPKB met een vraag voor een verandering van de huidige regeling. De VPKB bleek zeer bereid tot gesprek, maar beperkt bereid om, na bijna 150 jaar relatieve stabiliteit in haar relatie met de overheid, de dringende (en dwingende) vraag van de EAV voor een radicale structurele verandering snel te honoreren. De EAV besloot daarom een strategische alliantie aan te gaan met de francofone evangelische alliantie, die ook onlangs was ingericht, om op nationaal niveau hun krachten te bundelen. Ze richtten daarbij hun aandacht niet primair op de mogelijkheden voor financiering van lokale eredienstplaatsen. Over de wenselijkheid daarvan waren de meningen immers verdeeld. ${ }^{20}$ Maar ze deelden een sterk verlangen om 'orthodoxie' te verdedigen (met name in het protestantse godsdienstonderwijs) en om nieuwe middelen van evangelisatie in te kunnen zetten (vooral zendtijd op radio en $\mathrm{tv}$ ).

Zoals elders beschreven, verliepen gesprekken met de VPKB in de ogen van de evangelische allianties zeer moeilijk. ${ }^{21}$ Daarom richtten de allianties zich na enkele jaren gezamenlijk tot de minister van Justitie, die in België verantwoordelijk is voor de erkenning van erediensten en filosofische organisaties. Tussen 1992 en 1997 trachtten zij de toenmalige minister van Justitie, Stefaan De Clercq (CVP), ervan te overtuigen dat de huidige regeling discriminerend was, aangezien vertegenwoordiging van een minderheid van het Belgische protestantisme, namelijk de VPKB, de enige gesprekspartner was van de overheid inzake de protestantse eredienst en dus monopolie had over de bijbehorende voordelen. In een reeks schriftelijke communicaties werden argumenten aan de minister gepresenteerd en verschillende onderhandelingstechnieken werden gebruikt door de evangelische allianties om hun slag thuis te halen. ${ }^{22}$ De minister verwees hen echter terug naar de VPKB om deze aangelegenheid intern op te lossen. Aangezien de evangelische allianties bij zowel de VPKB als de overheid bot vingen met hun dringende vraag, trachtten ze gezamenlijk zelf een nieuwe administratieve structuur uit te werken waarvan zij hoopten dat die in de toekomst het Belgische pro-

19 Dit inleidende historische gedeelte is noodzakelijk beknopt en selectief. Voor een meer gedetailleerde historiografie, zie J. Creemers, 'Evangelical Free Churches and State Support in Belgium: Praxis and Discourse from 1987 to Today', Trajecta 2015, p. 177-204; J. Creemers, 'All Together in One Synod? The Process of Structural Unification of Evangelical Free Churches in Belgium (1985-1998)', Trajecta 2018 (in druk).

20 Merk op dat de geciteerde statuten van de EAV vzw alle rechten benoemt die aan de erkende erediensten toekomen, behalve de steun voor lokale geloofsgemeenschappen. Men was het er lange tijd intern niet over eens of een 'vrije' kerk al dan niet geld van de overheid kon aanvaarden voor haar werking. Zie ook Creemers 2015, p. 177-204.

21 Zie vorige voetnoot.

22 In deze briefwisseling maakten zij strategisch gebruik van zelfcategorisering, dat wil zeggen, ze beschouwden zich bij momenten wel en bij andere momenten niet als deel van de categorie 'protestanten' en probeerden voordeel te halen uit zowel hun nabijheid tot het historisch protestantisme als hun afstand hiertoe. Zie J. Creemers, 'We Are (Kind of) Protestants Too! Self-Categorization of Free Church Evangelicals in Communications with the Belgian Authorities (1992-1997)', Journal of Church and State 2018. 
testantisme naar de overheid toe zou kunnen vertegenwoordigen. Deze structuur kreeg de naam 'Federale Synode van de Protestantse en Evangelische Kerken in België' (FS). De VPKB werd uitgenodigd om lid te worden, maar sloeg dit aanbod vriendelijk af. De nieuwe Federale Synode werd op 3 januari 1998 opgericht en telde toen twaalf evangelische en pinksterdenominaties als oprichtende leden, die in totaal ongeveer 220 geloofsgemeenschappen vertegenwoordigden. ${ }^{23} \mathrm{Nu}$ bestonden er dus in de VPKB en de FS twee grote overkoepelende structuren van protestantse gemeenschappen die zichzelf allebei beschouwden als hét orgaan dat het protestantisme zou moeten vertegenwoordigen naar de overheid toe, maar waarvan alleen nog de VPKB als zodanig formeel werd erkend door de overheid.

Toen minister De Clerq in de nasleep van de Dutroux-affaire op 24 april 1998 ontslag nam, werd hij vervangen door partijgenoot Tony Van Parijs. Van Parijs nam een andere houding aan jegens de zopas opgerichte Federale Synode en trachtte samen met hen een oplossing te vinden voor hun gebrek aan officiële vertegenwoordiging binnen het erkende protestantisme. Hij besloot in te zetten op een onderhandelde oplossing en stuurde aan op gestructureerde onderhandelingen tussen de VPKB en de FS. Na enkele voorbereidende gesprekken met elk van hen apart werden vertegenwoordigers van de VPKB en de FS op het ministerie uitgenodigd met het doel om samen een werkbare oplossing te vinden.

\section{VPKB-FS-onderhandelingen in aanwezigheid van het ministerie (1999-2002)}

De twee protestantse partijen begonnen deze officiële onderhandelingen in 1999 met zeer verschillende doelen en verwachtingen. ${ }^{24}$ De vertegenwoordigers van de VPKB vertrouwden op hun historische ervaring en hun stabiliteit als organisatie. Ze wilden hun voorzichtig opgebouwde structuren niet zomaar overboord gooien en hadden dus geen haast in de onderhandelingen. De vertegenwoordigers van de FS vertrouwden op hun numerieke overwicht en enkele rechtszaken inzake hun belangen in het protestantse godsdienstonderwijs, die ze onlangs gewonnen hadden. ${ }^{25} \mathrm{Zij}$ streefden naar een snelle onderhandeling en wilden een volledig nieuw representatief orgaan opbouwen, gebaseerd op een parlementaire structuur waarin hun diversiteit en meerderheid zouden worden gerespecteerd.

Er was met uitdrukkelijke instemming van de protestantse partijen meestal een vertegenwoordiger van het ministerie aan de onderhandelingstafel aanwezig met een adviserende en bemiddelende rol. Hoewel duidelijk was dat de protestantse partijen zelf uiteindelijk tot een vergelijk moesten komen, is opmerkelijk dat aan het begin het uiteindelijke doel van de onderhandelingen krachtdadig werd vast-

23 Het aantal lidkerken van de FS is sindsdien gestaag blijven groeien. In 2001 was er al sprake van 250 kerken. Zie D. Vanescote aan de minister van Justitie, 1 juni 2001, CACPE Négociations (1999-2002), Archieven, of J.-L. Simonet, Archieven van de Federale Synode. Momenteel zijn ruim 530 kerkgemeenten lid van de FS. Zie http://fedsyn.be/adressen/kerken/, geraadpleegd op 8 maart 2018.

24 Dit is met name duidelijk uit de notulen van de eerste onderhandelingssessies. Zie de archieven van J.-L. Simonet, opgenomen in de archieven van de Federale Synode.

25 Voor meer informatie, zie Creemers 2018 (in druk). 
gelegd door het ministerie. Ten eerste moesten de onderhandelingen uitmonden in een enkel vertegenwoordigend orgaan, aangezien de minister geen twee gesprekspartners voor de protestantse eredienst zou aanvaarden. ${ }^{26}$ Ten tweede geven de notulen aan dat 'het Kabinet [aandrong] op een paritaire vertegenwoordiging in de samenwerkingsstructuur'. ${ }^{27}$ Het nieuwe representatieve orgaan moest dus twee 'vleugels' hebben, een VPKB-vleugel en een FS-vleugel, met gelijke stem. Dit werd als het enige model beschouwd dat tot een werkbare uitkomst kon leiden. De beslistheid van het ministerie om dit systeem op basis van pariteit vast te leggen werd erg duidelijk net voor de tweede onderhandelingsontmoeting. Enkele dagen voor deze zou plaatsvinden, werd ze geannuleerd door het ministerie. De notulen maken duidelijk dat de vertegenwoordigers van het ministerie niet tevreden waren met het concrete voorstel voor de samenwerkingsstructuur, dat door de FS (vrij laat) in voorbereiding op de vergadering was rondgestuurd: 'Deze tekst stemde niet overeen met het idee van het Ministerie (paritaire vertegenwoordiging). ${ }^{28}$

Aangezien de onderhandelaars van de Federale Synode een sterk numeriek overwicht claimden, was een tweevleugelstructuur op basis van pariteit voor hen geen vanzelfsprekend richtpunt. In een schrijven aan de minister van 24 maart 1999 werd hier dan ook tegen ingebracht dat eigenlijk 'een numerieke benadering van de structuur' in de lijn lag van hun 'democratische overtuiging'. ${ }^{29}$ Toch geeft dezelfde brief tevens de bereidheid aan om de genoemde basisvoorwaarden van het ministerie te aanvaarden. Het was waarschijnlijk duidelijk dat deze paritaire structuur niet onderhandelbaar was en men wilde het risico niet nemen om het welwillende oor van de minister te verliezen - evenals de potentieel positieve resultaten van deze onderhandelingen, waarop de achterban al lang wachtte. De bereidheid werd dan ook uitgesproken om deze structuur te verdedigen naar de achterban toe. Tegelijkertijd werd gepleit voor de mogelijkheid van een heronderhandeling van het pariteitsprincipe op langere termijn - bijvoorbeeld vijf of tien jaar.

Nadat deze eerste horde genomen was en een paritaire vertegenwoordiging door de FS was aanvaard, werden de onderhandelingen in de aanwezigheid van een

26 Procès-verbal du 10ème séance, 19 januari 2000, 'CACPE négociations (1999-2002)'; Archieven van J.-L. Simonet, Archieven van de Federale Synode. Het zij opgemerkt dat het volgens grondwetspecialist Adriaan Overbeeke in feite perfect mogelijk is om binnen de constitutionele kaders de vertegenwoordiging van erediensten naar de overheid toe op een andere manier te organiseren. Zie A. Overbeeke, 'Het hoofd verliezen. Over de vertegenwoordiging van een erkende godsdienst die uit meerdere denominaties bestaat (noot onder R.v.St. nr. 69631, 18 november 1997)', Publiekrechtelijke kronieken 1998, p. 192-205; A. Overbeeke, '(Eenheids-)vertegenwoordiging van erkende religies in het Belgische eredienstenrecht: Pleidooi voor een gedifferentieerde benadering', Recht, Religie en Samenleving 2013, p. 5-43.

27 Notulen van vergadering 2, 3 maart 1999, 'CACPE négociations (1999-2002)', Archieven van J.L. Simonet, Archieven van de Federale Synode, p. 4.

28 Notulen 22 vergadering, 3 maart 1999, 'CACPE négociations (1999-2002)', Archieven van J.-L. Simonet, Archieven van de Federale Synode.

29 P. Nullens aan mevr. Dekens, dhr. Tysebaert en dhr. Ghysselinckx, 24 maart 1999, 'Dossiers BFEG-OPEK 1998', EAV archieven. 
overheidsambtenaar systematisch constructief. Toch duurde het niet minder dan 58 sessies om alle details van de uiteindelijke structuur uit te klaren. Daarbij valt op dat een volgende moeilijke uitdaging voor de onderhandelaars niet hun eigen onderlinge relaties betrof, maar hun relatie tot drie andere protestantse partijen, die niet aan de onderhandelingstafel waren uitgenodigd door het ministerie. Deze partijen waren drie zeer verschillende groepen van protestantse origine die noch aan de VPKB, noch aan de FS verbonden waren: (a) een handvol orthodox-gereformeerde kerken in een los samenwerkingsverband onder de naam 'Gereformeerd Overleg Vlaanderen', (b) een aantal zogenoemde 'broedergemeenten', gekenmerkt door een grote terughoudendheid jegens bovenlokale gezagsstructuren, en (c) de Belgisch-Luxemburgse Federatie van Adventkerken, die een twintigtal geloofsgemeenschappen in het land telde. Deze drie onafhankelijke partijen waren in eerdere onderhandelingen betrokken geweest en wilden ook betrokkenheid in het toekomstige vertegenwoordigende orgaan, zonder zich echter bij de VPKB of bij de FS te willen aansluiten.

De beide partijen aan de onderhandelingstafel waren zich ervan bewust dat deze (en andere) onafhankelijke protestantse gemeenschappen niet bij de officiële gesprekken waren uitgenodigd. De vertegenwoordigers van de VPKB beschouwden hen voornamelijk als een bedreiging voor de tweevleugelstructuur, die nu werd voorbereid. ${ }^{30}$ Als deze externe stemmen een aparte plaats zouden krijgen in de toekomstige structuur, vreesden ze door een alliantie van de FS met hen in een minderheidspositie te worden gedrukt. De FS beschouwde een aparte integratie van de onafhankelijke partijen in de nieuwe structuur aanvankelijk nog als een goede manier om toekomstige politieke impasses te vermijden, die, zoals zij vreesden, onvermijdelijk zouden zijn in de paritaire tweevleugelstructuur. ${ }^{31}$ Toch besloten VPKB en de FS gezamenlijk om de derde partijen voor meer dan een jaar niet in de gesprekken te betrekken en zo de lopende onderhandelingen een goede kans van slagen te geven. Een eerste ontmoeting tussen de VPKB, de FS en de onafhankelijken werd pas georganiseerd nadat de VPKB en de FS waren overeengekomen dat het uiteindelijke representatieve orgaan en de werking van al zijn commissies de paritaire tweevleugelstructuur als uitgangspunt moesten hebben. Ze stelden in de eerste ontmoeting elk van de drie onafhankelijke partijen dan ook voor de keuze om zich bij een van de vleugels aan te sluiten of om een partnerschap met een van hen af te sluiten.

De notulen van het eerste gezamenlijke gesprek van FS, VPKB en de onafhankelijke partijen laten zien dat deze laatsten absoluut niet van de houding van de FS en de VPKB gediend waren. ${ }^{32} \mathrm{Zij}$ hadden verwacht dat dit gesprek hun de mogelijkheid zou geven om deel te nemen aan open onderhandelingen, niet dat het hen voor een vooraf vastgelegde keuze zou stellen. Ze gaven alle drie aan zich in de

30 Procès-verbal du 3ème séance, 31 maart 1999, 'CACPE négociations (1999-2002)', Archieven van J.-L. Simonet, Federale Synode Archieven.

31 P. Nullens aan mevr. Dekens, dhr. Tysebaert en dhr. Ghysselinckx, 24 maart 1999, 'CACPE négociations (1999-2002)', Archieven van J.-L. Simonet, Federale Synode Archieven.

32 Verslag 1e gesprek VPKB/FS/Onafhankelijken, 14 maart 2000, 'CACPE négociations (1999-2002)', Archieven van J.-L. Simonet, Federale Synode Archieven. 
theologische velden van respectievelijk de FS en de VKPB niet thuis te voelen anders zouden ze zich al wel bij een van hen aangesloten hebben. Daarom waren ze met name vlijmscherp naar de Federale Synode toe voor hun houding: 'Vroeger hebben jullie het exclusivisme aangevochten. Werkt de FS nu niet mee in het exclusivisme te verplaatsen? Wij zitten nu op de plaats van de FS vroeger!'33 De VPKB en de FS hielden echter voet bij stuk en stelden dat er simpelweg geen andere opties waren. Ze verwezen daarbij naar de rol van de overheid: 'Voor sommige dingen is er politieke wil, voor andere dingen niet.' 34

De onafhankelijke onderhandelaars contacteerden daarop het ministerie om dit te verifiëren, maar ze kregen van het ministerie een heel ander signaal: de overheid wenst één enkele gesprekspartner die het protestantisme in België vertegenwoordigt, 'maar verder wil het Ministerie zich niet mengen in de inwendige zaken van de kerken'. ${ }^{35}$ Er werd geopperd dat de recente machtswissel mogelijk de oorzaak was voor de gewijzigde positionering van het ministerie. ${ }^{36}$ Deze respons was verrassend voor de FS en de VPKB en plaatste hen in een lastig parket. Aangezien ze vreesden dat hun precaire onderhandelingen schade zouden oplopen als de tweevleugelstructuur opnieuw in vraag zou worden gesteld, ${ }^{37}$ namen ze eveneens contact op met het ministerie. Daar werd bevestigd dat de enige absolute voorwaarde van de overheid inderdaad was dat er slechts één representatief orgaan voor de protestantse eredienst zou worden ingericht. Tegelijkertijd begrepen ze echter dat het ministerie tevreden was met de huidige richting van de onderhandelingen. ${ }^{38}$

De notulen van de hieropvolgende ontmoetingen laten duidelijk zien dat de onderhandelaars van de Federale Synode erg met deze situatie worstelden. ${ }^{39} \mathrm{Ze}$ begrepen de kritiek van de derde partijen aan hun adres maar al te goed en ze waren er zich bovendien zeer van bewust dat een tweevleugelsysteem nooit hun verlangen was geweest. Bovendien leefde er een vrees dat de onafhankelijke partijen een rechtszaak tegen de onderhandelaars zouden aanspannen. Toch slaagden de onderhandelaars van de VPKB erin om hun gelijken bij de FS ervan te overtuigen het pariteitsprincipe niet los te laten. Zowel de VPKB als het ministerie beschouwde dit immers als de maximaal haalbare uitkomst van de onderhan-

33 Verslag 1e gesprek VPKB/FS/Onafhankelijken, p. 3.

34 Verslag 1e gesprek VPKB/FS/Onafhankelijken, p. 4.

35 L. Delameillieure aan D. Vanescote en J. van der Dussen, 20 juni 2000, 'CACPE négociations (1999-2002)', Archieven van J.-L. Simonet, Federale Synode Archieven.

$36 \mathrm{Na}$ de federale verkiezingen van 13 juni 1999 nam een paars-groene regering onder leiding van Guy Verhofstadt de plaats in van de rooms-rode coalitie onder leiding van Jean-Luc Dehaene. De liberaal Marc Verwilghen volgde op 12 juli 1999 de christendemocraat Tony Van Parijs op als minister van Justitie. Delameillieure stelde dat mogelijk het vorige ministerie aandrong op een tweepartijenstelsel, maar dat dit sinds de machtswissel blijkbaar niet meer het geval is. Zie vorige voetnoot.

37 Procès-verbal du 18ème séance, 4 juli 2000, 'CACPE négociations (1999-2002)', Archieven van J.L. Simonet, Federale Synode Archieven.

38 Notulen van de 19e vergadering, 13 juli 2000, 'CACPE négociations (1999-2002)', Archieven van J.-L. Simonet, Federale Synode Archieven.

39 Zie met name de notulen van de 23e vergadering, 15 november 2000, 'CACPE négociations (1999-2002)', Archieven van J.-L. Simonet, Federale Synode Archieven. 
delingen. De FS beschouwde dit een flinke stap vooruit vergeleken met de situatie waaruit ze kwam. Aangezien ze deze winst niet op het spel wilde zetten, besloot ze om loyaal te blijven aan het voorliggende voorstel. Hoe de FS met deze materie worstelde, blijkt duidelijk in de verrassende wijze waarop de mogelijkheid van een rechtszaak door een van haar onderhandelaars in hun discours werd geïntegreerd: 'Indien van hogerhand (de Raad van State/Rechtbank: zien we als een instelling van God) gezegd wordt dat wij andere christenen onrecht aandoen met onze manier van handelen, dan moeten wij ons neerleggen bij deze tussenkomst van God en overgaan naar 3 vleugels. ${ }^{40}$ De FS en de VPKB hielden dus vast aan de tweevleugelstructuur, tot grote frustratie van de onafhankelijke partijen, die hen beschuldigden van 'discriminatie door pragmatisme'. ${ }^{41}$

Omwille van de latente angst voor een rechtszaak werd een bijzondere ontmoeting georganiseerd tussen de onderhandelaars van de FS en de VPKB en verschillende woordvoerders van het ministerie. ${ }^{42}$ De ambtenaren verzekerden de twee onderhandelingspartners dat ze niet te vrezen hadden in een rechtszaak. De onafhankelijke partijen werden niet gediscrimineerd, zo werd gesteld, daar ze toch de mogelijkheid hadden om zich bij een van de twee vleugels aan te sluiten. Bovendien gaf de vertegenwoordiger van de minister aan dat hij bereid was om persoonlijk de derde partijen uit te nodigen voor een gesprek en te trachten hen ervan te overtuigen om zich bij de FS of de VPKB aan te sluiten. De onderhandelingspartners aanvaardden dit voorstel, ${ }^{43}$ en de daaropvolgende consultatie met de derde partijen op het ministerie had inderdaad het gewenste effect. ${ }^{44}$ In de volgende maanden werd de coalitie van de onafhankelijken ontbonden en besloot elk van hen om zich bij een van de twee vleugels aan te sluiten. ${ }^{45}$ Volgens de notulen van de FS/VPKB-onderhandelingen werd vanuit het Gereformeerd Overleg Vlaanderen uitdrukkelijk aangegeven dat het gesprek met de kabinetsmedewerker de doorslaggevende factor was geweest om tot een lidmaatschap bij de FS te besluiten.

Nadat deze horde genomen was, ijverden de onderhandelingspartners - en in het bijzonder de FS - hard om de tweevleugelstructuur op te zetten en ervoor te zor-

40 Idem.

41 Derde gesprek VPKB/FS/Onafhankelijken, 6 december 2000, 'CACPE négociations (1999-2002)', Archieven van J.-L. Simonet, Federale Synode Archieven.

42 Notulen ontmoeting ARPEE-afgevaardigden en het ministerie van Justitie, 13 december 2000, 'CACPE négociations (1999-2002)', Archieven van J.-L. Simonet, Federale Synode Archieven.

43 Notulen 27e vergadering, 7 maart 2001, 'CACPE négociations (1999-2002)', Archieven van J.-L. Simonet, Federale Synode Archieven.

44 Nochtans waren de onafhankelijke partijen na hun uitnodiging bij het ministerie kritisch op de poging van de overheidsambtenaar om hen ervan te overtuigen een kant te kiezen. Zij vonden dat hij daarmee buiten zijn rol trad. Procès-verbal Quatrième réunion EPUB/SF avec les trois Indépendants, 28 maart 2001, 'CACPE négociations (1999-2002)', Archieven van J.-L. Simonet, Federale Synode Archieven.

45 Het Gereformeerd Overleg Vlaanderen (GOV) en een 'vergadering van Darbisten' (een zgn. 'broedergemeente') sloten zich uiteindelijk aan bij de FS; de Belgisch-Luxemburgse Federatie van Adventkerken besloot tot een partnerschap met de VPKB. Vanuit het GOV werd naar het gesprek op het ministerie verwezen. Zie de notulen van vergadering 38, 14 november 2001, 'CACPE négociations (1999-2002)', Archieven van J.-L. Simonet, Federale Synode Archieven. 
gen dat ze goed dichtgetimmerd was. ${ }^{46}$ Verschillende commissies hadden tot dan toe met een redelijke autonomie diverse aspecten van de protestantse religiestaatrelatie behartigd. Deze commissies werden bewust opgenomen binnen de ARPEE en verloren daarmee hun redelijke zelfstandigheid. Zij werden in de nieuwe structuur hiërarchisch onderworpen aan een Centrale Raad, het hoogste beslissende orgaan, waar voortaan alle belangrijke beslissingen moesten worden genomen of bekrachtigd. De ARPEE, de Administratieve Raad voor de Protestants-Evangelische Eredienst, werd uiteindelijk op 1 januari 2003 opgericht, na een lange onderhandeling van meer dan zestig ontmoetingen, waarvan de meeste in de aanwezigheid van een ambtenaar van het ministerie van Justitie.

Vijftien jaar later is de ARPEE-structuur nog steeds overeind en onveranderd. Dit kan een teken zijn van de kracht van de ARPEE-structuur. Tegelijkertijd is het echter een publiek geheim dat deze structuur momenteel onder veel interne druk staat. Zoals eerder gezegd, had de FS gewenst dat het pariteitsprincipe na een periode van vijf tot tien jaar opnieuw onderhandelbaar zou zijn. Deze heronderhandeling werd echter nooit geopend, aangezien de uiteindelijke statuten bepaalden dat beide partijen daartoe bereid moesten zijn - hetgeen tot op de dag van vandaag niet het geval is geweest. Immers, het is een open vraag hoe een constructieve heronderhandeling van de structuur mogelijk is zonder dat dit een bedreiging voor een van de oprichtende partijen, in casu de VPKB, zou vormen.

\section{Conclusies}

Sinds 2003 is een meerderheid van evangelische en pinksterkerken in België opgenomen in een administratieve structuur, die hen toegang geeft tot bepaalde baten die integraal onderdeel zijn van de Belgische religie-staatregulering. De oprichting van die structuur, de ARPEE, was het resultaat van ruim vier jaar van intensieve onderhandelingen en meer dan vijftien jaar aan voorbereidingen. De voorgaande analyse van de onderhandelingen staat ons toe de volgende conclusies te maken.

Ten eerste valt op dat de Federale Synode in haar zoektocht naar medezeggenschap tot diverse en grote concessies bereid was. Ze zag af van de parlementaire structuur, die ruimte zou geven aan haar inwendige diversiteit. Ze stemde in met een op pariteit gebaseerd tweevleugelsysteem, dat haar numerieke overwicht buiten beschouwing liet. En ze accepteerde dat dit systeem enkel gewijzigd kon worden met toestemming van beide vleugels. Zelfs wanneer zij geconfronteerd werd met derde partijen die dezelfde discriminatie claimden als hun lidkerken ruim een decennium hadden ervaren, maakte ze zich niet hard voor wijzigingen die deze derde partij en haarzelf tot voordeel zouden strekken. Haar onderhandelingspartner en het ministerie beschouwden het pariteitsprincipe immers als onopgeefbaar, waardoor het als het maximaal haalbare positieve resultaat werd 
beschouwd. De partijen die de FS hadden opgericht, streefden al geruime tijd naar inspraak in dit dossier, en het voorafgaande proces had al tot veel frustraties geleid. Nu eindelijk verandering en inspraak in het verschiet lagen, werden deze concessies waarschijnlijk als noodzakelijk ervaren.

Ten tweede valt op dat, eens er in de onderhandelingen vooruitgang werd geboekt en een werkbare oplossing in zicht kwam, de Federale Synode zich bijzonder inspande om ervoor te zorgen dat de structuur goed uitgewerkt en dichtgetimmerd zou worden. In het proces van de onderhandelingen streefde ze naar een sterk hiërarchische structuur met zeer strikte taakomschrijvingen voor de commissies, die tot dan toe onder toezicht van de VPKB gestaan hadden. In deze oefening was de FS meer proactief en feller dan haar protestantse onderhandelingspartner of de overheidsvertegenwoordigers. Dit lijkt in sterke tegenspraak met de nadruk op vrijheid in structuur, die vele kerken en denominaties aangesloten bij de Federale Synode kenmerkt. Mogelijk is het echter te verklaren vanuit een wantrouwen jegens de gesprekspartner (VPKB) en is de ijver te verstaan als een poging een eventuele nieuwe toekomstige machtsstrijd te vermijden.

Ten derde valt de cruciale rol op die doorheen het proces door de burgerlijke overheid gespeeld werd. Het ministerie van Justitie opende en faciliteerde de onderhandelingen. De op pariteit gebaseerde tweevleugelstructuur werd bij het begin van de onderhandelingen krachtdadig door zijn vertegenwoordigers als einddoel neergezet. En zijn vertegenwoordigers stelden de onderhandelaars gerust toen die vreesden dat de onderhandelingen door derde partijen in gevaar zouden kunnen worden gebracht. Een vertegenwoordiger van het ministerie was daarbij bereid om leden van de derde partijen te ontmoeten en hen ervan te overtuigen zich bij de situatie neer te leggen. Ten slotte - maar dat is in dit artikel niet eerder besproken - was het ministerie aan het eind van de onderhandelingen tot financiele toegevingen bereid om de onderhandelingen finaal te laten landen. ${ }^{47}$ De mate van overheidsinmenging in dit specifieke (protestantse) dossier is beperkt vergeleken met haar optreden tegenover (de organisatie van) de islamitische eredienst. ${ }^{48}$ Deze analyse toont echter eveneens duidelijk aan dat de neutraliteit, die de overheid vooropstelt in haar omgang met de (minderheids)erediensten, ook de bij de protestantse eredienst meer wens dan realiteit is.

Met de afronding van deze onderhandelingen is het dus duidelijk in welke richting de evangelische vertegenwoordigers betreffende de eerder aangehaalde dilemma's bewogen zijn. De oprichting van de ARPEE heeft evangelische kerken en organisaties langgewenste mogelijkheden gegeven om politieke invloed uit te oefenen in de materies die de protestantse religie-staatverhouding in België aanbelangen. Voor de operationalisering daarvan hebben zij echter ten dele hun zeer gewaardeerde autonomie moeten prijsgeven. Het doorlopen proces van institutio-

47 Het betreft het financieren van een secretaris voor de FS reeds één jaar voor de oprichting van de ARPEE, alsook het erkennen en bezoldigen van twee covoorzitters van de ARPEE, die respectievelijk de voorzitters van elk van de vleugels zijn.

48 Voor een recent overzicht van de plaats van de (gestructureerde) islam in België, zie N. Fadil, 'Belgium,' in: J.S. Nielsen (red.), Yearbook of Muslims in Europe (vol. 6). Leiden 2014, p. 83-107. Een klassieke pre-9/11 studie is die van Panafit 1999. 
nalisering heeft hen op eis van de overheid tot de vorming van een dichtgetimmerde, sterk hiërarchisch representatief orgaan gedwongen, waarin ze structureel aan elkaar en aan de VPKB vastgeklonken zijn. Of daarmee de protestanten in België vandaag meer verenigd zijn dan dertig jaar geleden, is een andere vraag. Structureel wordt binnen de ARPEE vandaag in België een grotere variëteit aan protestanten bij elkaar gebracht dan ooit eerder - en deze diversiteit dijt nog gestaag uit. Maar deze structurele eenheid is echter duidelijk opgezet voor zeer specifieke gunstmaatregelen van de staat - en tot op opvallende hoogte ook door de staat. 